Research Article (Araştırma Makalesi)

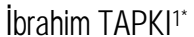

Nuran TAPKI²

Yusuf Ziya GÜZEY1

(1) $0000-0002-4552-6941$

(1) $0000-0001-5044-795 X$

Muhammet Hanifi SELVI1 1 0000-0002-9785-9174

${ }^{1}$ Hatay Mustafa Kemal University, Agriculture

Faculty, Animal Science Department, 31001 Hatay

${ }^{2}$ Hatay Mustafa Kemal University, Agriculture

Faculty, Agriculture Economy Department,

31001 Hatay

Corresponding author: ibtapki@mku.edu.tr

Keywords:

Dairy cow, genetic correlation, type, production, profitability.

\section{Genotypic Correlations among First Lactation Profitability, Linear Type Traits and Production Characteristics of Holstein Friesian Cows in Turkey}

Türkiye'de Yetiştirilen Siyah Alaca İneklerin Doğrusal Tip Özellikleri, Birinci Laktasyon Karlılığı ve Verim Özellikleri Arasındaki Genotopik Korelasyonlar

Alıış (Received): 07.10.2019 Kabul tarihi (Accepted): 18.06.2020

\begin{abstract}
Objective: The aim of this study is to determine genetic correlations between linear type traits, yield characteristics and first lactation profitability for use in selection programs.

Material and Methods: The research was carried out in Hatay province between 20122017. A total of 810 cows in the first lactation were used in the study. Analysis of variance and covariances of genetic parameters was carried out with Multivariate Limited Maximum Likelihood test.

Results: The average first lactation net profit, 305-d milk yield, first calving age, conception rate at first service, and calving ease rate were determined as 540 US\$, 6008 $\mathrm{kg}, 793 \mathrm{~d}, 61.6 \%$, and $91.7 \%$, respectively. Heritabilities of linear type and production traits ranged from 0.10 to 0.42 and 0.04 to 0.39 , respectively. The genetic correlations between first lactation profitability and type traits ranged from -0.08 and 0.42 , while between first lactation profitability and production traits ranged from 0.06 and 0.34 . The highest genetic correlation was between first lactation profitability and central ligament $(0.42)$, while the lowest genetic correlation was between first lactation profitability and udder depth (-0.08). The highest genetic correlation was between first lactation profitability and lactation protein yield $(0.34)$, while the lowest genetic correlation was between first lactation profitability and conception rate at first service $(0.09)$. Genetic correlations between type and production traits varied from -0.42 (FA and CFS) to 0.49 (DC and 305-d MY).

Conclusion: These results showed that primiparous cows having more angular, strong fore udder attachments, strong foot and legs structure were more profitable and opportunities of selection programs by using genetic correlations between linear type traits and production characteristics. It also concluded that the first lactation profitability could be used successfully in Turkish dairy cattle breeding programs.
\end{abstract}

\section{öz}

Amaç: Bu çalışmanın amacı, ıslah programlarında kullanılmak üzere doğrusal tip özellikleri, verim özellikleri ve birinci laktasyon karlıı̆̆ı arasındaki genetik korelasyonların tespitini yapmaktır.

Materyal ve Metot: Araștırma 2012-2017 yılları arasında Hatay ilinde yürütülmüştür. Araşıtırmada toplam 810 bas birinci laktasyonda olan inek kullanılmıştır. Genetik parametrelerinin varyans ve kovaryanslarının analizi ise Multivariate Limited Maximum Likelihood testi ile gerçekleştirilmiştir.

Bulgular: Ortalama inek başına birinci laktasyon net kar, 305-gün süt verimi, ilk buzağılama yaşı, ilk tohumlamada gebe kalma oranı ve kolay doğum oranı 540 US\$, $6008 \mathrm{~kg}, 793$ gün \%61.6 ve \%91.7 olarak belirlenmistir. Doğrusal tip özellikleri ile verim özelliklerinin kalıtım dereceleri sırasıyla; $0.10-0.42$ ve 0.04-0.39 arasında tahmin edilmiştir. Birinci laktasyon karlılı̆̆ ile doğrusal tip özellikleri arasındaki genetik korelasyonlar -0.08 ve 0.42 arasında, birinci laktasyon karlı̆ı̆ı ile verim özellikleri arasındaki korelasyonlar 0.06 ve 0.34 . arasında tahmin edilmiştir. Birinci laktasyon karlılı̆ı ile en yüksek korelasyonu meme merkez bağı (0.42) gösterirken, en düşük korelasyonu meme derinliği (-0.08) göstermistir. Yine birinci laktasyon karlılı̆ı ile en yüksek korelasyonu süt proteini verimi (0.34) gösterirken, en düşük korelasyonu ilk tohumlamada gebe kalma oranı (0.09) göstermiştir. Doğrusal tip özellikleri ile verim özellikleri arasındaki genetik korelasyonlar -0.42 (Ayak açısı ve ilk tohumlamada gebe kalma oranı) ile 0.49 (Sütçü tip özelliği ve 305-gün süt verimi) arasında değişiklik göstermiş̧ir.

Sonuç: Araştırma sonuçları, birinci laktasyondaki daha fazla sütçü tipe sahip, ön meme bağlantısı güçlü, güçlü ayak ve bacak yapısına sahip ineklerin, birinci laktasyonda daha karlı olduklarını ve süt sığıı ıslah programlarında doğrusal tip özellikleri ile verim özellikleri arasındaki bu genetik korelasyonlardan yararlanılarak, daha isabetli seleksiyon yapılabileceğini ortaya koymuştur. 


\section{INTRODUCTION}

Milk production is the primary target of dairy cattle breeding. Milk, fat, and protein yields and fat and protein percentages are the main economic characteristics for selection in modern dairy cattle production. Accurate estimates of genetic parameters are required to estimate reproduction values using mixed models or selection indices (Chauhan and Hayes, 1991). Recently, functional traits such as reproductive and health characteristics have been more focused on biological, economic and ethical causes and also because of animal welfare concerns. The profitability of dairy cattle depends not only on the production of milk but also on non-production traits such as fertility and health (Toghiani, 2012; Dahiya et al., 2020). Today's production efficiency in farm animals has become the primary concern of breeders in the livestock industry. Increasing profitability by enhancing gross income per cow is in the milestone of breeders in the last decades (Zwald et al., 2004). The phenomenon, fertility, is a combination of several aspects that numerous definitions have given. Pryce et al. (2004) portrayed fertility as "the accomplishment of pregnancy at the desired time" whereas Hyppanen and Juga (1998) described it as "the ability to produce a living offspring during the economically and physiologically approved period". Fertility is "the ability of the animal to conceive and maintain pregnancy if served at the appropriate time in relation to ovulation" according to Darwash et al. (1997) and reported as the ability of the cow to return on heat within an acceptable period, to show the heat properly, and to become pregnant with a minimum number of inseminations; by DeGroen et al. (1997) and (Tiezzi and Maltecca, 2011). Due to the continuous deterioration of genetic structure in terms of health and production traits, more functional traits except for production traits have been taken as selection criteria in selection programs in international genetic evaluations (Berry et al., 2004). As a result of the long-time interval required and problems in recording related production traits, identifying additional traits that can easily be measured and have larger heritability of the individual traits of interest has risen. Linear type traits define biological sense for a series of visual traits of the cow (Berry et al., 2004).

Eighteen functional type traits which approved by the International Committee for Animal Recording (ICAR) used in this research are evaluated in the genomic selection of bulls in intensive dairy cattle production (Anonymous, 2018). The linear type traits program of Wilson (1979) is widely utilized in most countries by dairy breed associations and artificial insemination (Al) organizations. Production traits have become the primary target of dairy cattle breeders in the whole world. Unfavorable genetic correlations between fertility and production resulted in a severe phenotypic and genetic decline in the dairy industry (Makgahlela et al., 2009). Karslıoglu Kara et at. (2010) stated that cows' productive life was determined 36.8 \pm 2.60 month and it was found that $50 \%$ of cows were culled from voluntary reasons, while $50 \%$ of involuntary reasons. In another study, Yaylak (2007) expressed that it was found significant that correlations of body depth with dairy form (0.29), body depth with depth udder $(-0.54)$, rear udder height with rear udder width (0.46), rear udder width with rear legs rear view (0.51), dairy form with rump width (0.31). Correlations among major classification categories with linear descriptive traits for all parity were found generally low and medium level and significantly. Numerous studies were conducted to measure the effect and importance of functional type traits and production characteristics on lactation profitability in modern dairy cattle production (PerezCabal and Alenda, 2002; Caraviello et al., 2003; Forabosco et al., 2004; Forabosco et al., 2005; PerezCabal et al., 2005; Sewalem et al., 2005; Sewalem et al., 2008).

There are only a small number of studies in which the genetic correlations between a cow's economic profitability, production, and linear type traits were estimated from their embryo stage to the end of the first lactation period. The main objective of this study was to investigate the genetic relationships between first lactation profitability, linear type traits, and production characteristics of Holstein Friesian cows.

\section{MATERIALS and METHOD}

This research was conducted in five private dairy cattle farms between 2012-2017 in Hatay, Turkey. The farms are located between $36^{\circ} \mathrm{E} 20$ longitudes and 36 ${ }^{\circ} \mathrm{N} 18$ latitudes in the Eastern Mediterranean region of Turkey. Similar five dairy farms in terms of herd management, feeding, housing and use of technology were selected from the members of Hatay Dairy Cattle Breeding Association. A total of 810 head primiparous cows and 16 sires, which had at least 20 daughters, were used in 5 dairy farms. The linear type scoring was made following the guidelines of the International Committee for Animal Recording (ICAR, 2010).

Dairy farms were visited at weekly intervals, records of production traits, and her pedigrees were collected. Also, eighteen linear type traits were scored 
on a scale of 1-9 at the beginning of the first lactation just before morning milking (between 15-30 days postpartum). Cows were milked twice a day, morning and evening.

UNIVARIATE test was used for the analysis of normality of population data and the analysis of means and standard deviations using GLM (General Linear Model) procedure, and Chi-Square (nonparametric) test of SPSS was used for the statistical analysing of conception rate at first service and calving ease traits (SPSS Version 22.0, 2015). The variance and covariance components of the genetic parameters were determined as Multivariate Limited Maximum Likelihood (MTDFREML) by using an animal model. (Boldman et al., 1995).

The following basic models with fixed effects were used;

$$
Y_{i p j k l}=\mu_{p}+H_{j}+Y_{k}+S_{l}+a(x-\bar{x})+e_{i p j k l}
$$

where:

$Y_{\mathrm{ipjk}}=$ observation for trait $\mathrm{p}$ on animal $\mathrm{i}$,

$\mu_{\mathrm{p}}=$ overall mean value for trait $\mathrm{p}$, farms)

$H_{j}=$ fixed effect of $j$. Herds (1., 2., 3., +...5. dairy

$\mathrm{Y}_{\mathrm{k}}=$ fixed effect of k.calving year $(2012,2013,2014$, 2015, 2016 and 2017)

$\mathrm{S}_{\mathrm{I}}=$ fixed effect of $\mathrm{I}$. calving season (spring, summer, autumn and winter),

$a(x-\bar{x})=$ regression on the production traits,

$\mathrm{e}_{\mathrm{ipjk}}=$ residual effect (random error).

Maternal age and the first breeding age were taken as the covariant factors.

A compound of production and linear type traits defines the biological portion of profit per cow. Only the profitability values of the cows in the first lactation period were taken into account in the calculation of revenue and costs. In calculating the revenues, costs and firs lactation net profits of cows, the prices in the year when the cows were in the first lactation period were taken as basis. Profit per cow was defined as the difference between returns and costs, with returns (R) and costs (C) as follows;

$$
\begin{aligned}
& \text { Returns:[(FLMY } \times \text { MP) + AMQI + LCP + MVD }] \\
& \text { Costs:[CFC + CMP + HOC + CFC + CWOC + DEP }]
\end{aligned}
$$

Where, FLMY was the first lactation milk yield $(\mathrm{kg})$; MP was milk price; AMQI was additional milk income including subventions, incentives, bonuses, cooled and qualified milk; LCP was live calf price; MVD was monetary value difference of cow from other contemporary cows having high genetic merit in relation to high milk yield and good linear type traits; CFC was calf food costs including milk, hay and concentrate feed; CMP was calf mortality price; COC was other contemporary calves cost related to calf rearing (veterinary, labor, housing, medicine, vaccine etc), CFC was cow food costs including hay, concentrate feed, CWOC was other contemporary cows' costs (veterinary, labor, housing, medicine, vaccine, insemination etc.). The useful life of the cows was taken as 5 years in depreciation calculate and the depreciation was calculated by dividing the marketing values of the cows by its useful life. If a cow did not have a first lactation period greater than $305 \mathrm{~d}$, its returns and costs were not corrected and they were considered as the actual value of the first lactation period.

\section{RESULTS and DISCUSSION}

The means, standard deviations and descriptions of linear type and production traits are summarized in Table 1. According to Table 1, the average scores of the type traits ranged from 3.01 (foot angle) to 7.12 (rump width). The average scores of conformation type traits such as dairy character, rump angle, rear leg sets, foot angle, fore-udder attachment, udder depth, rear udder height, central ligament, rear teat placement, hock development, and locomotion were evaluated as low levels. The average scores regarding the type traits are closely similar to the results reported by Gökçe and Burgut (2019). Gökçe and Burgut (2019) stated that the avarage scores of stature, dairy character, body depth, rump width, rump angle, rear legs side view, chest width, foot angle rear legs placement, rear legs rear view, fore udder attachment, rear udder height, suspensory ligament, udder depth, teat placement, teat length and rear teat placement linear type traits were $144,21 \pm 2,03 \mathrm{~cm} ; 6,23 \pm 0,63 ; 5,78 \pm 0,71 ; 5,03 \pm 0,58$; $5,90 \pm 0,71 ; 5,03 \pm 0,91 ; 5,36 \pm 0,60 ; 4,76 \pm 0,66 ; 4,55 \pm 0,71$; $4,59 \pm 0,94 ; 4,95 \pm 0,98 ; 4,64 \pm 0,81 ; 5,93 \pm 0,89 ; 5,28 \pm 0,92$; $5,71 \pm 0,84 ; 4,70 \pm 0,51$ and $5,12 \pm 0,86$ respectively.

Heritability values and genetic relationships between first lactation profits (US\$) and linear type traits are shown in Table 2 . The heritabilities of type traits varied from 0.10 (foot angle and central ligament) and 0.42 (dairy character). Heritabilities of all foot, leg, and udder type traits were estimated as low or moderate. Also, the heritability of first lactation profit was estimated as 0.35 . The dairy character, stature, hock development, teat length, and first lactation profit traits had higher heritability values than the other all type traits. Genetic relations between first lactation profit (US\$) and type traits 
Table 1. Average scores of linear type traits and production characteristics (means $\pm S E$ )

Çizelge 1. Doğrusal tip özellikleri ile üretim özelliklerine ait ortalamalar ve standart hataları

\begin{tabular}{|c|c|c|c|c|c|}
\hline Linear Type Traits & Abbreviations & $\begin{array}{c}\text { SCORES } \\
1\end{array}$ & 9 & Mean & S.E \\
\hline Stature & STA & Short & Tall & 5.35 & 0.59 \\
\hline Chest width & $C W$ & Narrow & Wide & 6.42 & 0.64 \\
\hline Body depth & $\mathrm{BD}$ & Shallow & Deep & 6.11 & 0.57 \\
\hline Dairy character & DC & Tight rib & Open rib & 3.37 & 0.31 \\
\hline Rump angle & RA & High pins & Very slope & 3.14 & 0.40 \\
\hline Rump width & RW & Narrow & Wide & 7.12 & 0.81 \\
\hline Rear leg set (rear) & RLSR & Hock-in & Parallel & 3.98 & 0.28 \\
\hline Rear leg set (side) & RLSS & Straight & Sickled & 3.26 & 0.21 \\
\hline Foote angle & FA & Low & Very steep & 3.01 & 0.30 \\
\hline Fore-udder attachment & FUA & Loose & Strong & 3.74 & 0.25 \\
\hline Teat length & $\mathrm{TL}$ & Short & Long & 5.79 & 0.63 \\
\hline Udder depth & UD & Below hock & Shallow & 4.68 & 0.37 \\
\hline Rear udder height & RUH & Very low & High & 4.31 & 0.33 \\
\hline Front teat placement & FTP & Outside & Inside & 5.56 & 0.40 \\
\hline Central ligament & $\mathrm{CL}$ & Broken (flat) & Strong & 3.92 & 0.20 \\
\hline Rear teat placement & RTP & Outside & Crossing & 4.52 & 0.31 \\
\hline Hock development & HD & Swollen & Dry & 3.78 & 0.35 \\
\hline Locomotion & L & Short stride & Long stride & 4.16 & 0.30 \\
\hline \multicolumn{6}{|l|}{ Production Traits* } \\
\hline First lactation profit (US\$) & PFL & & & 540 & 51.2 \\
\hline Lactation length (d) & LL & & & 314 & 34.7 \\
\hline 305-d milk yield (kg) & MY & & & 6008 & 807.2 \\
\hline 305-d fat yield (kg) & $\mathrm{FY}$ & & & 229 & 27.3 \\
\hline 305-d protein yield (kg) & PY & & & 233 & 30.6 \\
\hline First breeding age (d) & FBA & & & 487 & 63.3 \\
\hline First calving age $(\mathrm{d})$ & FCA & & & 793 & 92.8 \\
\hline Services per conception & SC & & & 2.1 & 0.19 \\
\hline Conception rate in the first (\%) & CFS & & & 61.6 & 4.2 \\
\hline Interval to first service (d) & IFS & & & 81.4 & 6.4 \\
\hline Open days $(\mathrm{d})$ & OD & & & 138 & 12.2 \\
\hline Calving ease (\%) & CAEAS & & & 91.7 & 8.7 \\
\hline
\end{tabular}

*All production traits except first breeding and calving age are belong to the first lactations

Table 2. Heritabilities $\left(h^{2}\right)$ and genetic relatioships $\left(r_{g}\right)$ between first lactation profit and type traits (means \pm SE)

Çizelge 2. Doğrusal tip özellikleri ile birinci laktasyon karlılık durumuna ait kalıtım dereceleri ve özellikler arasındaki genotipik korelasyonlar (ortalama \pm SH)

\begin{tabular}{lcc}
\hline Linear Type Traits & Heritabilities & $\begin{array}{c}\text { Genetic } \\
\text { correlations }\end{array}$ \\
\hline First lactation profit (US \$) & $0.35 \pm 0.05$ & ----- \\
Stature & $0.39 \pm 0.04$ & $0.04 \pm 0.00$ \\
Chest width & $0.26 \pm 0.05$ & $0.20 \pm 0.01$ \\
Body depth & $0.27 \pm 0.03$ & $-0.06 \pm 0.00$ \\
Dairy character & $0.42 \pm 0.08$ & $0.40 \pm 0.06$ \\
Rump angle & $0.20 \pm 0.02$ & $0.09 \pm 0.00$ \\
Rump width & $0.20 \pm 0.01$ & $0.16 \pm 0.01$ \\
Rear leg set (rear) & $0.24 \pm 0.02$ & $0.21 \pm 0.03$ \\
Rear leg set (side) & $0.20 \pm 0.01$ & $0.37 \pm 0.05$ \\
Foot angle & $0.10 \pm 0.01$ & $0.25 \pm 0.03$ \\
Fore-udder attachment & $0.14 \pm 0.01$ & $0.27 \pm 0.02$ \\
Teat length & $0.36 \pm 0.04$ & $0.05 \pm 0.00$ \\
Udder depth & $0.19 \pm 0.02$ & $-0.08 \pm 0.00$ \\
Rear udder height & $0.12 \pm 0.01$ & $0.23 \pm 0.03$ \\
Front teat placement & $0.15 \pm 0.02$ & $0.31 \pm 0.04$ \\
Central ligament & $0.10 \pm 0.01$ & $0.42 \pm 0.04$ \\
Rear teat placement & $0.18 \pm 0.02$ & $0.29 \pm 0.03$ \\
Hock development & $0.37 \pm 0.04$ & $0.25 \pm 0.02$ \\
Locomotion & $0.28 \pm 0.03$ & $0.26 \pm 0.03$ \\
\hline
\end{tabular}

varied from -0.08 (udder depth) and 0.42 (central ligament). The type traits showing the highest genetic correlation with the first lactation profitability were central ligament, dairy character, rear leg set (side), and front teat placement (Table 2). The genetic correlations are similar to Prestes et al., 2017). The heritabilities of foot, leg and udder traits agree with the other research results (Short et al., 1991; Brotherstone, 1994; Gengler et al., 1999; Pryce et al., 2001; Pérez-Cabal et al., 2005; Némcová et al., 2011), without Mrode and Swanson (1994), Dahiya (2005), Dal Zotto et al. (2007), and Viegas et al. (2015) that heritabilities of foot and leg traits were expressed in higher or lower levels in these studies than this study. Most udder traits had low heritabilities except for teat length (0.36). The heritability values of most udder traits were similar to previously published studies (Mrode and Swanson, 1994; Veerkamp and Brotherstone 1997; Vollema and Groen, 1997; Toghiani, 2011; Bohlouli et al., 2015; Viegas et al., 2015; Prestes et al., 2017). 
The other functional traits in strict relationship with the body size had mostly moderate level heritabilities without dairy form (0.42) (Table 2). In this study, the heritabilities of body traits are consistent with those reported by Gengler et al. (1999), Špehar et al. (2012) and Prestes et al. (2017).

The heritabilities of production traits were estimated between 0.04 (open days) and 0.39 (lactation fat yield). Genetic correlations between first lactation profit (US\$) and production traits ranged from 0.06 (first breeding age) and 0.42 (lactation protein yield). The heritabilities of production traits and genetic relationships between the first lactation profit and production traits varied from 0.04 (open days) to 0.39 (lactation fat yield) and from 0.05 (interval to the first service) to 0.34 (lactation protein yield). All reproductive traits had low heritabilities (Table 3). The heritabilities of reproductive traits are in agreement with Cue et al. (1990), Dematawewa and Berger (1998), Weigel and Rekaya (2000), Berry et al.
(2003), Kadarmideen (2004), Biffani et al. (2005), Mitchell et al. (2005), Banos et al. (2007), Gredler et al. (2007) and Sun et al. (2010).

Table 3. Heritabilities $\left(h^{2}\right)$ and genetic relations $\left(r_{g}\right)$ between first lactation profit and production traits (means $\pm \mathrm{SE}$ )

Çizelge 3. Üretim özellikleri ile birinci laktasyon karlıık arasındaki genotipik korelasyonlar $\left(r_{g}\right)$ ve özelliklere ait kalıtım dereceleri $\left(h^{2}\right)$ (ortalama $\pm \mathrm{SH}$ )

\begin{tabular}{lcc}
\hline Production Traits & Heritabilities & $\begin{array}{c}\text { Genetic } \\
\text { correlations }\end{array}$ \\
\hline First lactation profit (\$US/per cow) & $0.35 \pm 0.04$ & ---- \\
Lactation length (d) & $0.15 \pm 0.01$ & $0.24 \pm 0.03$ \\
305-d milk yield (kg) & $0.31 \pm 0.02$ & $0.31 \pm 0.02$ \\
Lactation fat yield (kg) & $0.39 \pm 0.04$ & $0.33 \pm 0.04$ \\
Lactation protein yield (kg) & $0.38 \pm 0.05$ & $0.34 \pm 0.02$ \\
First breeding age (d) & $0.08 \pm 0.01$ & $0.06 \pm 0.00$ \\
First calving age (d) & $0.08 \pm 0.01$ & $0.27 \pm 0.03$ \\
Services per conception & $0.09 \pm 0.01$ & $0.20 \pm 0.01$ \\
Conception rate at first service (\%) & $0.05 \pm 0.01$ & $0.09 \pm 0.01$ \\
Interval to first service (d) & $0.12 \pm 0.02$ & $0.05 \pm 0.01$ \\
Open days (d) & $0.04 \pm 0.01$ & $0.11 \pm 0.02$ \\
Calving ease (\%) & $0.27 \pm 0.03$ & $0.24 \pm 0.03$ \\
\hline
\end{tabular}

Table 4. Means of economic parameters, revenues, costs and total net profit of cows Çizelge 4. Ineklerin yıllık gelir, gider ve net karı gibi ekonomik parametrelerine ait ortalamalar

\begin{tabular}{|c|c|c|c|}
\hline Parameters & Minimum & Maximum & Means \\
\hline Cow's price in calving (US\$) & 1875 & 2325 & 2065 \\
\hline Milk sales price (US\$) & 0.231 & 0.277 & 0.257 \\
\hline 305-d milk yield (kg) & 4786 & 7234 & 6008 \\
\hline Total net profit (US\$) & 373 & 712 & 540 \\
\hline \multicolumn{4}{|l|}{ Revenues (US\$) } \\
\hline Live calf value & 451 & 502 & 475 \\
\hline Total milk sales & 1505 & 1915 & 1639 \\
\hline Additional milk sales supports & 26 & 73 & 53 \\
\hline Average total revenue per cow & & & 2167 \\
\hline \multicolumn{4}{|l|}{ Costs (US\$) } \\
\hline Veterinary and medicine costs of cow's mother & 27 & 145 & 59 \\
\hline Veterinary and medicine costs per cow & 95 & 131 & 107 \\
\hline Insemination cost of cow's mother & 26 & 74 & 40 \\
\hline Insemination cost per cow & 34 & 86 & 58 \\
\hline Labour cost of cow's mother & 13 & 50 & 29 \\
\hline Labour cost per cow & 206 & 259 & 224 \\
\hline Feeds cost per cow & 782 & 1014 & 865 \\
\hline Depreciation cost per cow & 238 & 358 & 245 \\
\hline Total cost per cow & & & 1627 \\
\hline
\end{tabular}

The detailed statistics of economic parameters are summarized in Table 4. According to Table 4, the total cost, revenue and net profit per cow in the first lactation were calculated as 1627, 2167, and 540 US\$, respectively.

Genetic correlations between linear type and production traits varied from -0.47 (between rump angle and interval to first service) and 0.49 (between dairy character and lactation milk yield) (Table 5). There were positive correlations between dairy character and lactation length, 305-d milk, fat, and protein yields, while a negative correlation was found between dairy character and services per conception. The services per conception and conception rate at first service were negatively affected in taller cows. Services per conception increased, while the conception rate at first service of taller cows decreased. There were negative correlations between chest width and services per conception, the interval to first service, open day, and calving ease, while positive correlations were found between body depth, rump angle, rear leg set (side) and hock development, and calving ease. Rear udder height positively affected lactation length, milk, fat, and protein yields, but negatively affected services per conception, conception rate at first service, the interval to first service and open day. There were positive correlations between body depth and calving ease, while negative 
correlations were found between body depth and services per conception, and open days. Also, there was a positive correlation between fore udder attachment and services per conception (Table 5). The results of this study are similar to Cue et al. (1990) and Berry et al. (2004) and Yaylak (2007), but were not in agreement with Shapiro and Swanson (1991), and
Bohlouli et al. (2015). These differences may be due to the difference in methodology of heritability estimation, different linear type traits scoring methods and/or cattle population used. In general, linear models (applied to categorical variables) gave lower heritabilities than threshold models, and animal models gave higher heritability than sire models.

Table 5. Genotypic $\left(r_{g}\right)$ relations between 18 conformation type and 11 production traits means (above) and S.E (below)

Çizelge 5. Onsekiz konformasyon ve onbir üretim özelliği arasındaki genotipik korelasyonlar (yukarıdaki) ve standart hataları (aşağıdaki)

\begin{tabular}{|c|c|c|c|c|c|c|c|c|c|c|c|}
\hline Type Traits & LL & LMY & LFY & LPY & FBA & FCA & SC & CFS & IFS & OD & CAEAS \\
\hline \multirow[t]{2}{*}{ Stature } & 0.11 & 0.28 & 0.15 & 0.09 & -0.26 & -0.23 & -0.46 & -0.37 & -0.24 & -0.31 & 0.30 \\
\hline & $(0.01)$ & $(0.04)$ & $(0.01)$ & $(0.00)$ & $(0.03)$ & $(0.02)$ & $(0.07)$ & $(0.05)$ & $(0.03)$ & $(0.03)$ & $(0.02)$ \\
\hline \multirow[t]{2}{*}{ Chest width } & 0.20 & 0.28 & 0.21 & 0.14 & 0.31 & 0.25 & -0.36 & 0.03 & -0.43 & -0.38 & -0.38 \\
\hline & $(0.01)$ & $(0.03)$ & $(0.02)$ & $(0.01)$ & $(0.04)$ & $(0.03)$ & $(0.05)$ & $(0.00)$ & $(0.06)$ & $(0.05)$ & $(0.05)$ \\
\hline \multirow[t]{2}{*}{ Body depth } & 0.17 & 0.27 & 0.22 & 0.17 & -0.33 & 0.19 & -0.44 & 0.18 & -0.13 & -0.39 & 0.39 \\
\hline & $(0.01)$ & $(0.02)$ & $(0.02)$ & $(0.01)$ & $(0.04)$ & $(0.01)$ & $(0.06)$ & $(0.01)$ & $(0.01)$ & $(0.06)$ & $(0.06)$ \\
\hline \multirow[t]{2}{*}{ Dairy character } & 0.41 & 0.49 & 0.46 & 0.47 & 0.32 & 0.37 & -0.41 & -0.29 & 0.30 & -0.15 & -0.17 \\
\hline & $(0.05)$ & $(0.06)$ & $(0.06)$ & $(0.05)$ & $(0.03)$ & $(0.05)$ & $(0.05)$ & $(0.03)$ & $(0.03)$ & $(0.01)$ & $(0.01)$ \\
\hline \multirow[t]{2}{*}{ Rump angle } & 0.12 & 0.32 & 0.34 & 0.33 & 0.07 & -0.13 & -0.23 & 0.02 & -0.47 & 0.22 & 0.43 \\
\hline & $(0.01)$ & $(0.03)$ & $(0.03)$ & $(0.04)$ & $(0.00)$ & $(0.02)$ & $(0.03)$ & $(0.00)$ & $(0.05)$ & $(0.02)$ & $(0.06)$ \\
\hline \multirow[t]{2}{*}{ Rump width } & 0.09 & 0.31 & -0.06 & -0.01 & 0.26 & 0.12 & 0.27 & 0.14 & -0.33 & -0.30 & 0.29 \\
\hline & $(0.00)$ & $(0.04)$ & $(0.00)$ & $(0.00)$ & $(0.03)$ & $(0.02)$ & $(0.03)$ & $(0.01)$ & $(0.03)$ & $(0.03)$ & $(0.03)$ \\
\hline \multirow[t]{2}{*}{ Rear leg set (rear) } & 0.29 & 0.02 & 0.10 & 0.09 & 0.31 & 0.24 & 0.01 & 0.01 & -0.32 & 0.27 & 0.01 \\
\hline & $(0.03)$ & $(0.00)$ & $(0.01)$ & $(0.00)$ & $(0.04)$ & $(0.03)$ & $(0.00)$ & $(0.00)$ & $(0.03)$ & $(0.02)$ & $(0.00)$ \\
\hline \multirow[t]{2}{*}{ Rear leg set (side) } & 0.27 & 0.41 & 0.45 & 0.38 & 0.44 & 0.39 & 0.02 & 0.02 & -0.41 & 0.27 & 0.42 \\
\hline & $(0.04)$ & $(0.04)$ & $(0.06)$ & $(0.05)$ & $(0.06)$ & $(0.05)$ & $(0.01)$ & $(0.00)$ & $(0.04)$ & $(0.04)$ & $(0.05)$ \\
\hline \multirow[t]{2}{*}{ Foot angle } & 0.23 & 0.20 & 0.12 & 0.03 & 0.29 & 0.19 & -0.01 & -0.04 & 0.16 & 0.19 & -0.23 \\
\hline & $(0.02)$ & $(0.01)$ & $(0.01)$ & $(0.00)$ & $(0.03)$ & $(0.02)$ & $(0.00)$ & $(0.01)$ & $(0.01)$ & $(0.02)$ & $(0.01)$ \\
\hline \multirow[t]{2}{*}{ Fore udder attachment } & -0.09 & -0.14 & -0.12 & -0.07 & 0.02 & 0.06 & 0.43 & 0.31 & -0.30 & -0.27 & 0.01 \\
\hline & $(0.00)$ & $(0.01)$ & $(0.01)$ & $(0.00)$ & $(0.00)$ & $(0.01)$ & $(0.05)$ & $(0.04)$ & $(0.02)$ & $(0.03)$ & $(0.00)$ \\
\hline \multirow[t]{2}{*}{ Teat length } & 0.04 & -0.04 & -0.09 & -0.01 & 0.01 & -0.04 & 0.06 & 0.01 & 0.19 & 0.23 & 0.02 \\
\hline & $(0.00)$ & $(0.00)$ & $(0.00)$ & $(0.00)$ & $(0.00)$ & $(0.01)$ & $(0.01)$ & $(0.00)$ & $(0.01)$ & $(0.02)$ & $(0.00)$ \\
\hline \multirow[t]{2}{*}{ Udder depth } & -0.39 & -0.44 & -0.41 & -0.46 & 0.29 & 0.27 & -0.11 & -0.01 & -0.13 & -0.15 & 0.09 \\
\hline & $(0.05)$ & $(0.03)$ & $(0.04)$ & $(0.07)$ & $(0.04)$ & $(0.03)$ & $(0.01)$ & $(0.00)$ & $(0.01)$ & $(0.01)$ & $(0.01)$ \\
\hline \multirow[t]{2}{*}{ Rear udder height } & 0.40 & 0.42 & 0.45 & 0.43 & 0.16 & 0.11 & -0.38 & -0.40 & -0.41 & -0.38 & 0.12 \\
\hline & $(0.04)$ & $(0.05)$ & $(0.05)$ & $(0.05)$ & $(0.01)$ & $(0.01)$ & $(0.05)$ & $(0.05)$ & $(0.05)$ & $(0.05)$ & $(0.01)$ \\
\hline \multirow[t]{2}{*}{ Front teat placement } & 0.26 & 0.24 & 0.20 & 0.18 & 0.27 & 0.12 & 0.11 & 0.13 & 0.10 & 0.14 & 0.11 \\
\hline & $(0.03)$ & $(0.02)$ & $(0.02)$ & $(0.02)$ & $(0.03)$ & $(0.01)$ & $(0.01)$ & $(0.01)$ & $(0.01)$ & $(0.01)$ & $(0.02)$ \\
\hline \multirow[t]{2}{*}{ Central ligament } & 0.33 & 0.29 & 0.25 & 0.31 & 0.11 & 0.07 & 0.15 & 0.25 & 0.06 & -0.08 & -0.07 \\
\hline & $(0.04)$ & $(0.03)$ & $(0.03)$ & $(0.03)$ & $(0.01)$ & $(0.00)$ & $(0.01)$ & $(0.02)$ & $(0.01)$ & $(0.01)$ & $(0.01)$ \\
\hline \multirow[t]{2}{*}{ Rear teat placement } & 0.24 & 0.30 & 0.20 & 0.23 & 0.02 & 0.01 & -0.29 & 0.03 & 0.25 & 0.27 & 0.02 \\
\hline & $(0.02)$ & $(0.04)$ & $(0.02)$ & $(0.02)$ & $(0.00)$ & $(0.00)$ & $(0.03)$ & $(0.01)$ & $(0.03)$ & $(0.03)$ & $(0.00)$ \\
\hline \multirow[t]{2}{*}{ Hock development } & -0.21 & -0.24 & -0.19 & -0.16 & 0.32 & 0.30 & 0.31 & 0.20 & 0.19 & 0.15 & 0.41 \\
\hline & $(0.02)$ & $(0.02)$ & $(0.01)$ & $(0.01)$ & $(0.03)$ & $(0.04)$ & $(0.02)$ & $(0.02)$ & $(0.01)$ & $(0.01)$ & $(0.05)$ \\
\hline \multirow[t]{2}{*}{ Locomotion } & 0.21 & 0.19 & 0.17 & 0.14 & 0.25 & 0.21 & 0.29 & 0.16 & 0.10 & 0.09 & 0.20 \\
\hline & $(0.02)$ & $(0.01)$ & $(0.01)$ & $(0.02)$ & $(0.02)$ & $(0.01)$ & $(0.03)$ & $(0.01)$ & $(0.01)$ & $(0.01)$ & $(0.02)$ \\
\hline
\end{tabular}

LL: Lactation length, LMY: Lactation milk yield, LFY: Lactation fat yield, LPY: Lactation protein yield, FBA: First breeding age, FCA: First calving age,

SC: Services per conception, CFS: Conception rate at first service, IFS: Interval to first service, OD: Open days, CAEAS: Calving ease.

\section{CONCLUSIONS}

The cows that had a genetically taller and wider body, more angulars, shallower udders with lower foot angle, toe-out rear legs, higher pins rump angle had lower genetic merit for services per conception, conception rate at first service, the interval to the first service, open days and calving ease, while genetically more angular, higher rear udder heights had higher genetic merit for lactation length, milk, fat and protein yields. These results showed that primiparous cows having more angular, strong fore udder attachments, strong foot and legs structure were more profitable and opportunities of selection programs by using genetic correlations between linear type traits and production characteristics. It also concluded that the first lactation profitability could be used successfully in Turkish dairy cattle breeding programs.

\section{ACKNOWLEDGEMENTS}

The authors thanks the dairy farm owners and Hatay Dairy Cattle Breeders' Association. 


\section{REFERENCES}

Anonymous. 2018. Official rules governing type classification. Brown Swiss Cattle Breeders' Association of the U.S.A. http://www.brownswissusa.com (25 May 2018).

Banos G, Brotherstone S, Coffey MP. 2007. Prenatal maternal effects on body condition score, female fertility and milk yield of dairy cows. Journal of Dairy Science, 90: 3490-3499. DOI:https://doi.org/10.3168/jds.2006-809.

Berry DP, Buckley F, Dillon P, Evans RD, Rath M, Veerkamp. RF. 2003. Genetic reletionships among body condition score, body weight, milk yield and fertility in dairy cows. Journal of Dairy Science, 86: 2193-2204. DOI:https://doi.org/10.3168/jds.S00220302(03)73809-0.

Berry DP, Buckley F, Dillon P, Evans RD, Veerkamp RF. 2004. Genetic relationships among linear type traits, milk yield, body weight, fertility and somatic cell count in primiparous dairy cows. Irish Journal of Agricultural and Food Research, 43: 161-176.

Biffani S, Marusi M, Biscarini F, Canavesi F. 2005. Developing a genetic evaluation for fertility using angularity and milk yields as correlated traits. Interbull Bulletin, 33: 63-66.

Bohlouli M, Alijani S, Varposhti MR. 2015. Genetic relationships among linear type traits and milk production traits of Holstein dairy cattle. Annals of Animal Science, 15(4): 903-917. DOI: https://doi.org/10.1515/aoas-2015-0053.

Boldman KG, Kriese LA, Van Vleck CP, Van Tassell CP, Kachman SD. 1995. A Manual for Use of MTDFREML: A Set of Programs to Obtain Estimates of Variances and Covariances. Usd-Ars, Clay Center, Nebraska, USA.

Brotherstone S. 1994. Genetic and phenotypic correlations between linear type traits and production traits in Holstein Friesian dairy cattle. Animal Production, 59: 183-188.

Caraviello DZ, Weigel KA, Gianola D. 2003. Analysis of the relationship between type traits, inbreeding, and functional survival in Jersey cattle using a Weibull Proportional Hazards Model. Journal of Dairy Science, 86 (9): 2984-2989. DOI:https://doi.org/10.3168/jds.S0022-0302(03)73896-X.

Cue RI, Monardes HG, Hayes JF. 1990. Relationships of calving ease with type traits. Journal of Dairy Science, 73: 3586-3590. DOI:https://doi.org/10.3168/jds.S0022-0302(90)79060-1.

Chauhan VPS, Hayes JF. 1991. Genetic parameters for first lactation milk production and composition traits for Holsteins using multivariate restricted maximum likelihood. Journal of Dairy Science, 74: 603-610. DOI:https://doi.org/10.3168/jds.S00220302(91)78207-6.

Dahiya SP. 2005. Linear functional type traits for reproductive efficiency in Hariana cows. Indian Journal of Animal Sciences, 75 (5): 524-527.

Dahiya S, Kumar S, Kumar M. 2020. Current status of research on linear type traits in Indian cattle and future strategies. Tropical Animal Health and Production, 52(4): (electronically published), DOI: https://doi.org/10.1007/s11250-020-02302-w.

Dal Zotto R, De Marchi M, Dalvit C, Cassandro M, Gallo L, Carnier P, Bittante G. 2007. Heritabilities and genetic correlations of body condition score and calving interval with yield, somatic cell score, and linear type traits in Brown Swiss cattle. Journal of Dairy Science, 90: 5737-5743. DOI: https://doi.org/10.3168/jds.20070280 .

Darwash AO, Lamming GE, Woolliams JA. 1997. Estimation of genetic variation in the interval from calving to postpartum ovulation of dairy cows. Journal of Dairy Science, 80: 1227-1234. DOI:https://doi.org/10.3168/jds.S0022-0302(97)76051-X.

DeGroen AF, Steine T, Colleau JJ, Pedersen J, Pribyl J, Reinsch N. 1997. Economic values in dairy cattle, with special reference to functional traits. Report of an EAAP-working group. Livestock Production Science, 49: 1-21

DOI:https://doi.org/10.1016/S0301-6226(97)00041-9.
Dematawewa CM, Berger PJ. 1998. Genetic and phenotypic parameters for 305- day yield, fertility, and survival in Holsteins. Journal of Dairy Science, 81: 2700-2709.

DOI:https://doi.org/10.3168/jds.S0022-0302(98)75827-8.

Forabosco F, Groen AF, Bozzi R, Van Arendonk JAM, Filippini F, Boettcher P, Bijma P. 2004. Phenotypic relationships between longevity, type traits, and production in Chianina beef cattle. Journal of Animal Science, 82 (6): $572-1580$. DOI:https://doi.org/10.2527/2004.8261572x.

Forabosco F, Bozzi R, Boettcher P, Filippini F, Bijma P, Van Arendonk JAM. 2005. Relationship between profitability and type traits and derivation of economic values for reproduction and survival traits in Chianina beef cows. Journal of Animal Science, 83 (9): 2043. 2051. DOI:https://doi.org/10.2527/2005.8392043x.

Gengler N, Wiggans GR, Wright JR. 1999. Animal model genetic evaluation of type traits for five dairy cattle breeds. Journal of Dairy Science, 82 (6): 1350.e1-1350.e22. DOI:https://doi.org/10.3168/jds.S0022-0302(99)75359-2.

Gredler B, Fuerst C, Sölkner J. 2007. Analysis of new fertility traits for the joint genetic evaluation in Austria and Germany. Interbull Bulletin, 37: 152-155.

Gökçe G, Burgut A. 2019. Evaluation of Holstein cattle raised in research and application farm according to linear type traits. Çukurova Journal of Agricultural and Food Science, 34(1):17-26.

Hyppänen K, Juga J. 1998. Environmental and genetic effects on the 60-day nonreturn rate in Finnish AI bulls. Interbull Bulletin, 18: 92-95.

ICAR, 2010. International Committee for Animal Recording (ICAR). International agreement of recording practices. Guidelines Approved by the General Assembly Held in Riga, Latvia on June 2010, $527 \mathrm{p}$.

Kadarmideen HN. 2004. Genetic correlations among body condition score, somatic cell score, milkproduction, fertility and conformation traits in dairy cows. Animal Science, 79: 191-201. DOI:https://doi.org/10.1017/S1357729800090056.

Karslıŏglu-Kara N, Koyuncu M, Tuncel E. 2010. Longevity and Reasons for Culling in Holstein Dairy Cows. Journal of Animal Production, 51(1): 16-20.

Makgahlela ML, Mostert BE, Banga CB. 2009. Genetic relationships between calving interval and linear type traits in South African Holstein and Jersey cattle. South African Journal of Animal Science, 39 (1): 90-92.

DOI:https://doi.org/10.4314/sajas.v39i1.61221.

Mitchell RG, Rogers GW, Dechow CD, Vallimont JE, Cooper JB, Sander- Nielsen U, Clay JS. 2005. Milk urea nitrogen concentration: Heritability and genetic correlations with reproductive performance and disease. Journal of Dairy Science, 88: 4434-4440. DOI:https://doi.org/10.3168/jds.S00220302(05)73130-1.

Mrode RA, Swanson GJT. 1994. Genetic and phenotypic relationships between conformation and production traits in Ayrshire heifers. Animal Production, 58: 335-338.

DOI:https://doi.org/10.1017/S0003356100007261.

Némcová E, Štipková M, Zavadilová L. 2011. Genetic parameters for linear type traits in Czech Holstein cattle. Czech Journal of Animal Science, 4: 157-162. DOI:https://doi.org/10.17221/1435-CJAS.

Peréz-Cabal MA, Alenda R. 2002. Genetic relationships between lifetime profit and type traits in spanish Holstein cows. Journal of Dairy Science, 85: 3480-3491. DOI:https://doi.org/10.3168/jds.S0022-0302(02)74437-8.

Peréz-Cabal MA, Garcia C, Gonzáles-Recio O, Alenda R. 2005. Genetic and phenotipic reletionships among locomotion type traits, profit, production, longevity, and fertility in Spanish dairy cows. Journal of Dairy Science, 89: 1776-1783.

DOI:https://doi.org/10.3168/jds.S0022-0302(06)72246-9. 
Prestes Almeida T, Lurdes Kern E, dos Santos Daltro D, Neto JB, McManus C, Neto AT, Cobuci JA. 2017. Genetic associations between reproductive and linear-type traits of Holstein

cows in Brazil. Brazilian Journal of Animal Science, 46(2): 91-98.

Pryce JE, Coffey MP, Simm G. 2001. The relationship between body condition score and reproductive performance. Journal of Dairy Science, 84: 1508-1515. DOI:https://doi.org/10.3168/jds.S00220302(01)70184-1.

Pryce JE, Royal MD, Garnsworthy PC, Mao IL. 2004. Fertility in the high producing dairy cow. Livestock Production Science, 86:125. 135. DOI:https://doi.org/10.1111/j.1439-0531.2007.00906.x.

Shapiro LS, Swanson LV. 1991. Relationships Among Rump and Rear Leg Type Traits and Reproductive Performance in Holsteins. Journal of Dairy Science, 74: 2767-2773.

SPSS, 2015. SPSS for Windows, Version 2. SPSS Inc., Chicago, IL., USA.

Short TH, Lawlor TJ, Lee JR, Lee KL. 1991. Genetic parameters for three experimantal linear type traits. Journal of Dairy Science, 74: 2020-2025. 0302(91)78372-0.

Sewalem A, Kistemaker GJ, Van Doormaal BJ. 2005. Relationship between type traits and longevity in Canadian Jerseys and Ayrshires using a Weibull proportional hazards model. Journal of Dairy Science, 88 (4): 1552-1560. DOI:https://doi.org/10.3168/jds.S0022-0302(05)72824-1.

Sewalem A, Miglior F, Kistemaker GJ, Sullivan P, Van Doormaal BJ. 2008. Relationship between reproduction traits and functional longevity in canadian dairy cattle. Journal of Dairy Science, 91 (4): 1660-1668. DOI:https://doi.org/10.3168/jds.2007-0178.

Špehar M, Štepec M, Potočnik K. 2012. Variance components estimation for type traits in Slovenian Brown Swiss cattle. Acta Agriculturae Slovenica, 100 (2): 107-115.

Sun C, Madsen P, Lund MS, Zhang Y, Nielsen US, Su G. 2010. Improvement in genetic evaluation of female fertility in dairy cattle using multiple-trait models including milk production traits. Journal of Animal Science, 88: 871-878.

DOI:https://doi.org/10.2527/jas.2009-1912.
Tiezzi F, Maltecca C. 2011. Selecting for female fertility: What can be learned from the dairy experience. Beef Improvement Federation, Research Symposium \& Annual Meeting, p. 47-60, Montana, U.S.A.

Toghiani S. 2011. Genetic parameters and correlations among linear type traits in the first lactation of Holstein dairy cows. African Journal of Biotechnology, 10 (9): 1507-1510.

Toghiani S. 2012. Genetic relationships between production traits and reproductive performance in Holstein dairy cows. Archiv fur Tierzucht, 55 (5): 458-468. DOI:https://doi.org/10.5194/aab-55458-2012.

Veerkamp RF, Brotherstone S. 1997. Genetic correlations between linear type traits, food intake, live weight and condition score in Holstein dairy cattle. Animal Science, 64: 385-392. DOI: https://doi.org/10.1017/S1357729800015976.

Viegas Campos R, Cobuci JA, Kern EL, Costa CN, McManus CM 2015. Genetic parameters for linear type traits and milk, fat, and protein production in Holstein cows in Brazil. Asian Australasian Journal of Animal Sciences, 28(4):476-484. DOI: http://dx.doi.org/10.5713/ajas.14.0288

Vollema ANTR, Groen ABF. 1997. Genetic correlations between longevity and conformation traits in an upgrading dairy cattle populations. Journal of Dairy Science, 80: 3006-3014. DOI:Https://doi.org/ 10.3168/jds.S0022-0302(97)76267-2.

Weigel KA, Rekaya R. 2000. Genetic parameters for reproductive traits of Holstein cattle in California and Minnesota. Journal of Dairy Science, 83: 1072-1080. DOI: https://doi.org/10.3168/jds.S00220302(00)74971-X.

Wilson RD. 1979. A new system of evaluations. Hoard's Dairy Man, $124,1536-1537$.

Yaylak E. 2007. Phenotypic Correlations among Type Traits of Holstein Cows. Journal of Animal Production, 48(2): 19-26.

Zwald NR, Weigel KA, Chang YM, Welper RD, Clay JS. 2004.Genetic selection for health traits using producer-recorded data. I. Incidence rates, heritability estimates, and sire breeding values. Journal of Dairv Science. 87: 4287-4294.

DOI:https://doi.org/10.3168/jds.S0022-0302(04)73573-0. 